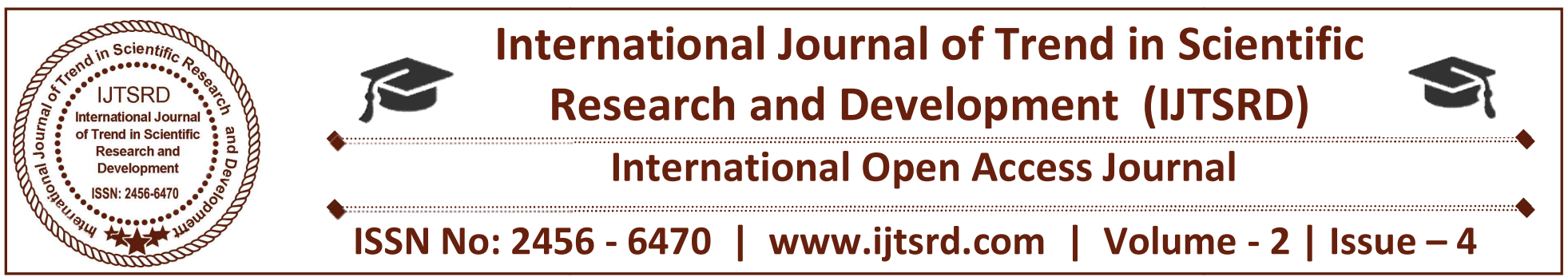

\title{
Natural Rubber: Its Constraints in foothills of Siang Region, Arunachal Pradesh
}

\section{Shri Kiryi Potom}

Ph.D. Research Scholar, Dept. of Geography

Rajiv Gandhi University, Rono Hills, Doimukh, Arunachal Pradesh, India
Prof. Tomo Riba

Professor, Dept. of Geography, Rajiv

Gandhi University, Rono Hills, Doimukh, Arunachal Pradesh, India

\section{ABSTRACT}

Knowledge about the uses of rubber tree was known to the people of Arunachal Pradesh since many years before. They used to collect its latex at early age from naturally grown Rubber Tree (ficuselastica) but this species is replaced by Heveabrasiliensis. First rubber was planted in 1980 for experimental purposes and it came to be used for commercial purposes since 1994. The study area is the main latex production area in the state. The study covered about the constraints for the rubber cultivation in the area. As per survey a report, people of the area is much interested to grow rubber but due to lots of constraints they could not reach at target. To achieve the objectives of the study, many tools have been used. For the reliability, information collected from sources and the field was analyzed by using MS word, MS excel and SPSS 18 package for generating appropriate qualitative and quantitative result. The information has been gathered through field investigation and 500 household from rubber cultivators were taken as sample. It is also found that 2,500.00 hectares (approx) of land under rubber plantation with 580 hectare under latex production.

Keywords: Natural rubber, plantation, transformation, Ficuselastica, hevea-brasiliensis, constraints

\section{INTRODUCTION}

Arunachal Pradesh fall in Non-traditional zone of rubber plantation and it has infancy stage in the field of rubber cultivation which begun in 1980 for experimental purposes and commercial rubber cultivation started since 1994. Despite of favorable condition of geographical background, it cannot reach at the impressive stage due to lots of constraints. So far, 2,500 (approx.) hectares area is covered under rubber plantation in the foothills of Siang Region of Arunachal Pradesh. Out of which total cultivated area, only 580 hectares are producing rubber latex. According to the Remote Sensing Survey of Rubber Board of India, Arunachal Pradesh has 25,000 hectares area which is suitable for the rubber cultivation especially in the foothills area.

\section{METHODS}

In order to achieve the laid objectives in the present study, information is collected from field investigation through filling of questionnaire of 500 sample households who presently cultivating rubber in small scale. The questionnaire was regarding information related to constraints faced by the small rubber growers of the foothills of Siang region. For the reliability, information collected from sources and the field was analyzed by using MS word, MS excel, MS publishers and SPSS 18 package for generating appropriate qualitative and quantitative results.

\section{DATA SOURCE}

Both Primary and Secondary source of data have been used for this purpose. Primary data was collected from the field itself, visiting rubber plantation sites, interviewing the cultivators, and other section of people who are related to rubber plantation. 
Secondary data was collected from published and unpublished books, journals, internet, institution like NEDFi, RBI, etc. An extensive literature review has been done to eliminate the biasness of information.

\section{RESULTS AND DISCUSSIONS}

Most of the constraints which are associated with rubber cultivation are similar in whole Arunachal Pradesh and North-East Region. The common difficulties of the study area are follows;

\section{a. Lack of Training Facilities:}

Another constraint of rubber farmer is absence of training center. That is why most of the growers failed in initial stage. In many cases, it is found that rubber plants have been damaged due to untrained tapper at the time of taping too. The processing of sap is very much technical to maintain the quality.

\section{b. Insufficient manpower}

Siang Region is located away from the Rubber Board of India. To reduce this difficulty the Rubber Boad of India established a Regional office for rubber in Ruksin under East Siang but it is found that the officer In-charge is available only on Monday to Tuesday in a week. Sometimes, he remains absent from the office for 20-25 days. The frequent transfer of the officer is also hampering the small rubber grower in the area. Very limited workshop has been organized for the rubber plantation so far due to absence of manpower in the area.

\section{c. Financial Constraints}

Most of the rubber farmers who have recently taken up rubber cultivation are small farmers who grew paddy. There is an initial incentive of financial assistance to a tune of Rs. 1,00,000/- to Rs. 1,50,000/. But such facilities are availed by few farmers and not the all. In order to develop one hectare of land for the rubber till it attains production level, a farmer has to spend following amount.

\section{d. Lack of suitable clones at the early period:}

It is found that, most of the cultivators in study area are innocent about better clones. Now, they are planting different rubber clones like RRII 105, RRII 430, RRII 414, RRII 429, RRIM 600, GT1, etc. in new fields. This ignorance of variety of crops suitable for different agro climatic area leads to poor performance in rubber production.
Researcher himself introduced a new rubber clone (RRII 208) in Arunachal Pradesh in 2016 which was newly released by Rubber Board of India during 9th Annual Rubber Conference of Association for Natural Rubber Producing Countries (ANRPC) in Guwahati on October 2016. This is the high yielding rubber clone which is suitable for a low temperature region, tolerant to wind damages, powdery mildew and abnormal leaf fall and has been considered exclusively for plantation in North-Eastern States of India.

\section{e. Climatic Hazard}

Rubber requires high temperature and enough rainfall. Sometimes, during peak monsoon the area receives excessive rainfall leading to leaches of top soil making it unfit for the growth of plants. Landslide in Siwalik belt is common during the rainy season leading to destruction of the fields. Bank cutting and deepening of river beds lead to underground seepage of water and drying of the fields.

Occasionally the natural disasters like landslide mostly in the foothills, flood in the plains, cyclone, etc. are detrimental to crops. In 2011 and 2014 cyclone damaged about 2-3 hectares of rubber field in Linka and Lumpo village of East Siang.

\section{f. Forest Fire}

Occurrence of the minor fire accident is common in the area. Till today, four major forest fire occurred in the study area destroying many rubber plants (1200 numbers) leading to great loss of years of hard efforts.

\section{g. Menace from animals}

One of the discouraging situations among rubber farmers is the damage of rubber tree by the domestic animals like cows, pig, goat and mithun (bosfrontail). Sometimes wild animals like deer, wild boar and porcupine damage the rubber plants.

Mr. BajumLikam of Lumpo village said, "Around 900-1,000 rubber saplings were completely damaged by animals during the initial stage in my field". According to Mr. TajumYinyo, his 1 to 3 years old rubber field was damages by the deer and wild boar in 2009.

\section{h. Topographical constraints}

Siang Region is mostly dominated by hilly and rough topography which discourages the rubber plantation 
because it is expensive in hilly area compared to plain. Though maximum part of Pasighat circle is plain and fertile but rubber cultivation is less due to strong gorge wind that damages tender rubber plants.

\section{i. Inaccessibility}

One of the most taxing situations among the farmers is the distant location of rubber gardens from villages. Daily commuting is an arduous work. Marketing of the final product is also problems due to lack of proper road to reach the market.

\section{j. Effect of Low Price}

There is no regulated price of rubber product. Market price used to fluctuate at the hands of businessmen. Sometimes price fall to discourage rate. Such fluctuation of price affects poor farmers. Individual small growers of the study areas seems to have adopted a "Wait and see" approach before new planting.

\section{k. Long Gestation Period}

The actual gestation period is six tyears, but sometimes it takes even more than seven years. This long waiting period after huge investment discourages many new farmers. Some farmers remain in the state of penury till the rubber gives return. But in other parts of the country, during this period, farmers remain engaged in other activities to substitute the gap period.

\section{Lack of fertilizers}

One of the reasons for slow growth of rubber plant is due to non-application of fertilizers. As per information collected from the existing rubber growers of the area, most of them are not applying fertilizers in their field due to its unavailability.

\section{m. Diseases}

It is recorded that poria root disease and pink disease have affected in few rubber fields in the study area. The farmers are using different measures to control the disease with consultation with nearby Field Officer, Rubber Board of India.

\section{n. Others}

Other problems faced by the rubber cultivators are insufficient supply of planting materials, and communication gap between farmers and the concern authority. Due to Absence of major trading or consuming centers, the farmers in the study areas are getting lower prices than their counterparts in traditional regions or other states.

\section{ACKNOWLEDGEMENT}

This research was partially supported by Prof. TomoRiba, my supervisor. I thank my all friends who showed support their and assist during the research. I thank my family members and other associated members for support and financial assistance during my data collection. I would also like to show my gratitude to the Regional Office Rubber Board and State Rubber Board for sharing data and pearls of wisdom with me during the course of this research.

\section{REFERENCES:}

1. Annamalainathan, K., Satheesh, P. R. and Jacob James (2011). Ecosystem flux measurements in rubber plantations.Natural Rubber Research, 24(1): 28-37, 2011.

2. AropeAni, Nor A. Mohm.andHua T. P. (1983). Rubber Owners' Manual: Economics and Management in production and marketing. RRIM.Kaula Lumpur. 334pp.

3. BaskarMohamad Abu. (2000). Agro-management of rubber Forest Plantation. Paper presented at the seminar on "Rubber Forest Plantation: Smart Partnership towards

4. Bindu Roy C., Sailajadevi, Raj Shammi, GogoiNripen Kr. and Mathew Jacob (2011). Is climate inimical to the development of abnormal leaf fall disease in natural rubber plantations in North-East India? Natural Rubber Research, 24(1): 132-139, 2011.

5. Desai Suseelendra and Rao M. Srinivasa (2011).Impact of climate change on insect pests, pathogens and their natural enemies.Natural Rubber Research, 24(1): 54-60, 2011.

6. Devanesan, S., Premila, K.S. and Shailaja, K.K. (2011). Influence of climate change on rubber honey production. Natural Rubber Research, 24(1): 54-60, 2011.

7. Ganguly, J.B. (Ed.) (1984). "Marketing in NorthEast India”. Omson Publications, Guwahati, New delhi.

8. Gireesh, T., Raj ShammiMydin, V and Mercykutty V.C. (2011). Rubber yield of certain 
International Journal of Trend in Scientific Research and Development (IJTSRD) ISSN: 2456-6470

clones of HeveaBrasiliensis and its relationship with climate variables.

9. Goswami, S.N., Challa, O. (October, 1, 2007). Economic analysis smallholder Rubbers Plantations in West Garo Hills District of Meghalaya.Indian Journal of Agricultural Economics.

10. Krishnamarchryulu, C.S.G and Lalita Ramakrishna (2003). "Rural Marketing", Published by Dorling Kindershy (India) Pvt. Ltd.

11. Wick, Henry A. (2012). On the plantation, cultivation and curing of Indian Rubber
(HeveaBrasiliensis) with an account of its introduction from the west to eastern tropics. International Journal of Agriculture, Environment and Biotechnology.

12. The Arunachal Times, Wednesday, January 23 and Tuesday, February $19 \&$ 23, 2013, March 4, $23 \& 26,2013$.

13. The Arunachal Times, Wednesday, January 23 and Tuesday, February $19 \& 23,2013$, March 4, 23, 262013.

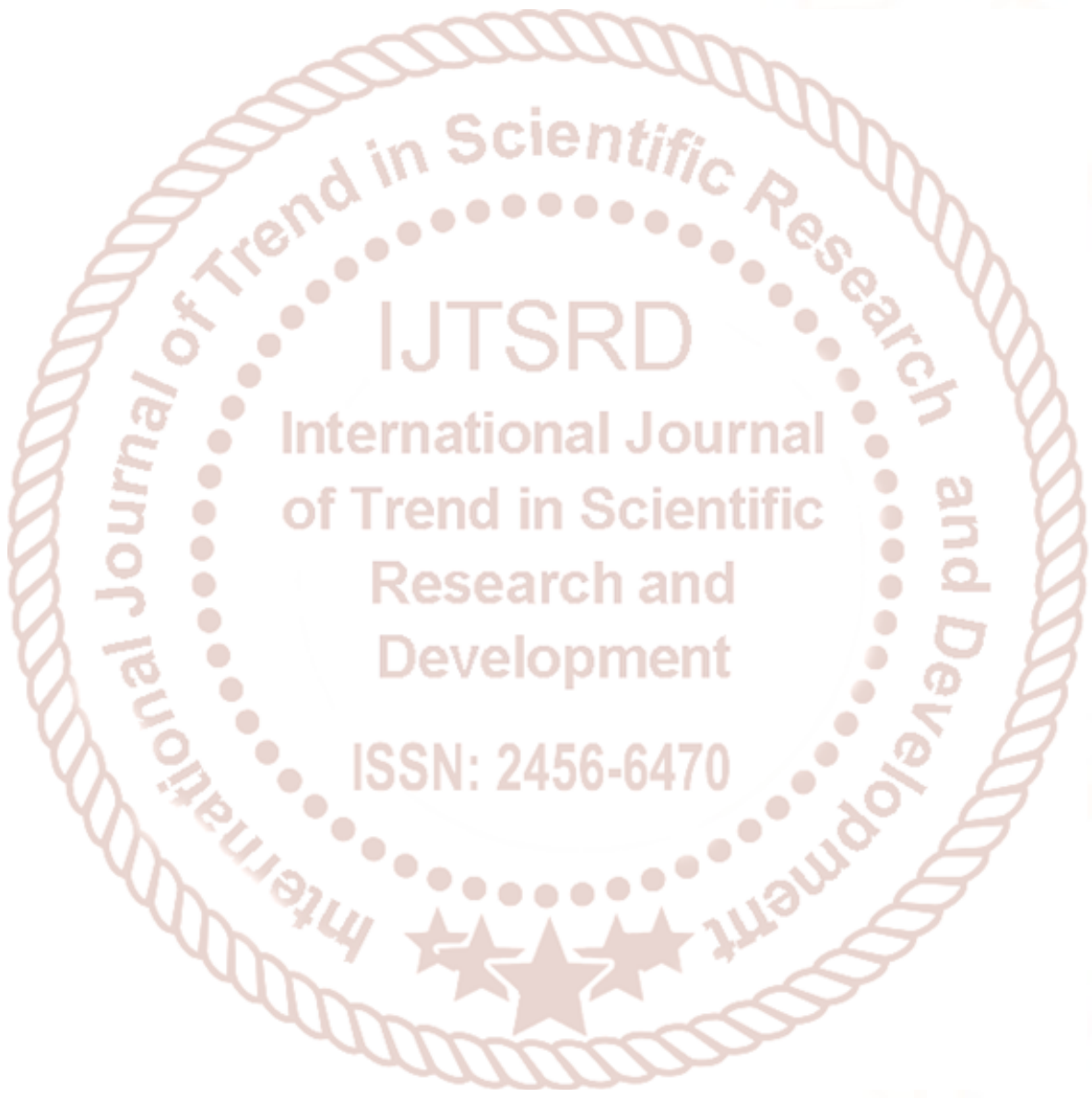

